\title{
CMA can't use proceeds of MD sale to fund physician pension plan
}

\author{
Cite as: CMAJ 2019 August 6;191:E874-5. doi: 10.1503/cmaj.109-5787
}

Posted on cmajnews.com on July 16, 2019.

$\mathrm{T}$ he Canadian Medical Association (CMA) cannot use the proceeds from its sale of MD Financial Management to set up a pension plan for its members, despite calls for such a move from some Canadian doctors. The lack of an employer-employee relationship means there is no legal basis for a pension plan, according to the CMA.

Dr. Artur Gevorgyan and Dr. Daren Lin began lobbying CMA last year to use the $\$ 2.6$ billion earned from the sale of the association's investment arm to Scotiabank to fund a pension plan for physicians. "We were surprised and upset by the sale of MD," says Lin. "For it to be sold and the money not to have a clear purpose felt like a betrayal."

Lin says many physicians struggle to save enough money for retirement, and the lack of financial certainty is a major cause of stress. "If we had some kind of safety net, we could use that energy on advocating for our patients or our own self-care," he says. "It would be great if the MD money could be used to help us all feel secure."

A petition started by Gevorgyan and Lin in March has gained more than 7500 signatures in support of the CMA establishing a Canadian national physician pension plan. The CMA was initially receptive to the idea, says Lin, and hired the human resources consulting firm Mercer to examine the pension landscape and provide options. But the report's conclusions convinced the CMA that a pension plan was not viable.

"[Mercer's] analysis confirmed that in the absence of employer-employee relationships, the CMA cannot legally create or contribute to a pension plan for phys-

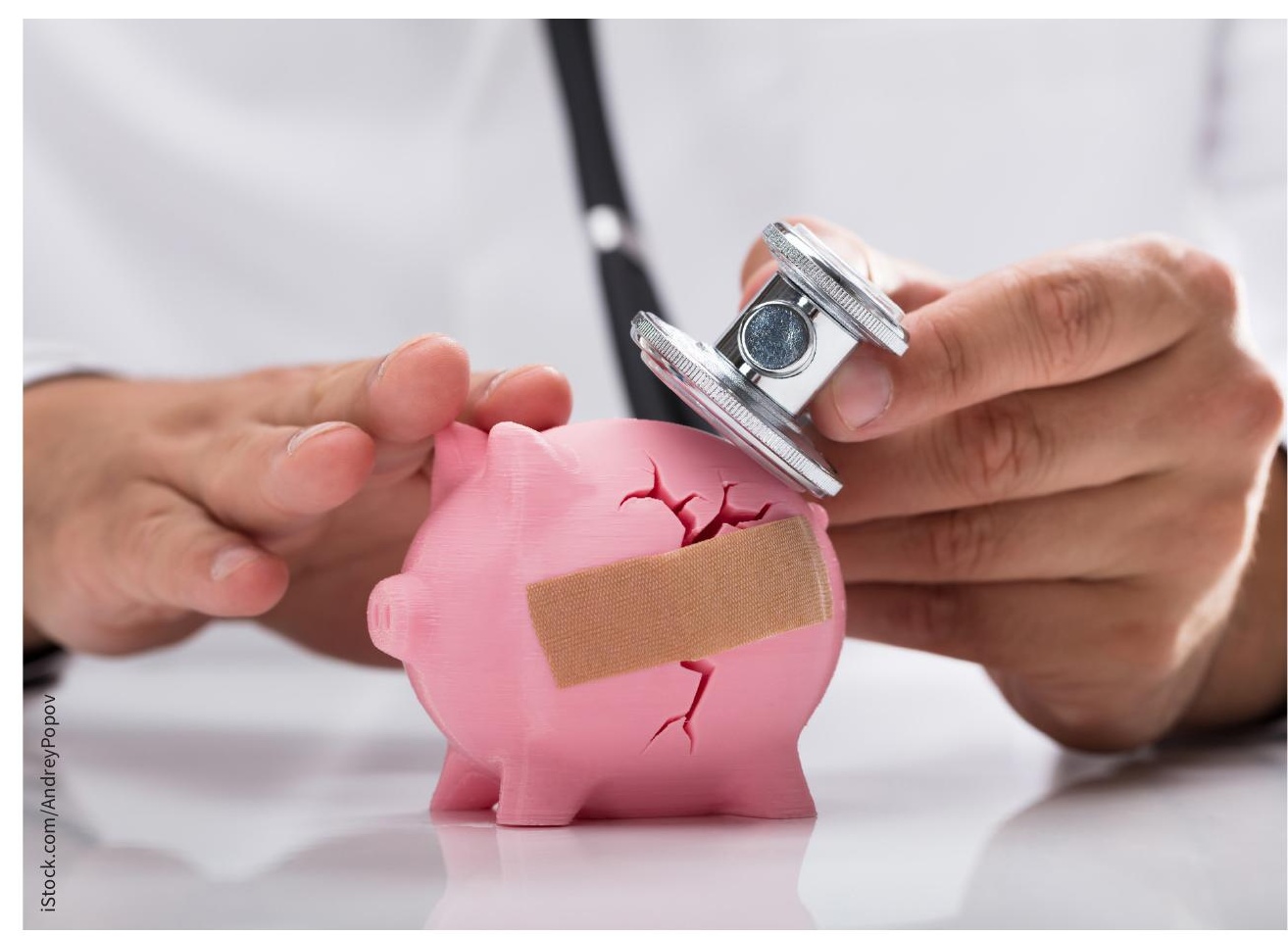

Some physicians say they struggle to save enough for retirement and it's a major cause of stress.

icians," CMA president Dr. Gigi Osler said in a statement.

The CMA can, however, "pursue federalprovincial advocacy to support retirement planning," she said. This could include lobbying for raising limits for tax-supported savings vehicles, raising passive income limits and expanding income splitting, or promoting the approach used in British Columbia, where the provincial government matches doctors' contributions to RRSPs.

"Findings from Mercer will be discussed with interested members and the provincial and territorial associations in the coming months so we can determine the most appropriate course of action that will benefit the profession the most," said Osler.

Gevorgyan says it seems like the CMA has shut the door on any plan to use the money from the MD sale to offer doctors more financial security. "I think it's their way of closing the issue of the sale and moving on without promising anything specific," he says. Gevorgyan says he asked to see the Mercer report, or at least the executive summary, on June 24 but has so far had no response.

The CMA has long known that creating a pension plan would require a change in law, says Dr. Mary Fernando. In 2005, the CMA accepted her motion at its general council to lobby the federal government 
to change tax laws to allow physicians to contribute to a pension while retaining their independence, but little was done to act on that mandate. "The onus is on the CMA to do this, and do it properly," she says. "Wasting money on a Mercer report that says what they already know makes no sense."

Similar provisions exist in other countries with a publicly funded health system, such as the United Kingdom. "This is not something special; it's just us catching up with the rest of the world," she says.
If changes to legislation are not forthcoming, alternative options exist, such as BC's RRSP matching program. The Ontario Medical Association (OMA) is also developing a pension-like product for its members. "We're looking to get as close to a pension as we can with existing financial products," says Dr. Paul Healey, physician committee member of the Voluntary Group Retirement Plan.

Many doctors are waiting to see what the CMA plans do to with the huge war chest from the MD sale, says Gevorgyan, and are expecting something big and transformational. Without that, many are questioning their membership, he says. "We need a reason to be members of the CMA, and right now a lot of my colleagues don't see one," says Gevorgyan.

The CMA has set up a new subsidiary, CMA Investco Inc., to oversee the investment of funds from the sale. "Returns from the invested funds will set up the CMA to support physicians and pursue its core advocacy and policy priorities long into the future," said Osler.

Brian Owens, St. Stephen, NB 